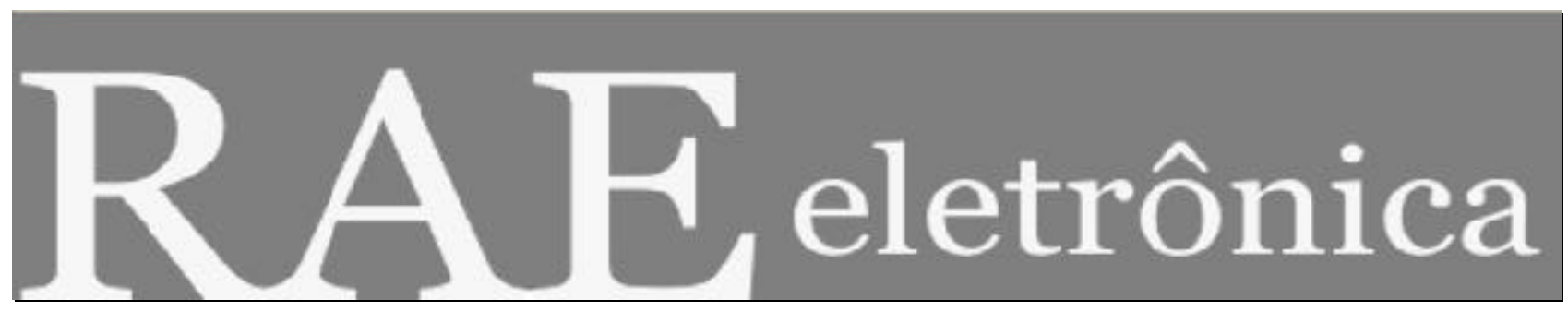

\title{
SISTEMAS ERP NO BRASIL: TEORIA E CASOS
}

Por:

\section{Ângela Freitag Brodbeck}

RAE-eletrônica, v. 3, n. 1, Resenha 1, jan./jun. 2004

http://www.rae.com.br/eletronica/index.cfm?FuseAction=Artigo\&ID=2240\&Secao=RESENHAS \&Vol ume $=3 \&$ Numero $=1 \&$ Ano $=2004$

CCopyright, 2004, RAE-eletrônica. Todos os direitos, inclusive de tradução, são reservados. É permitido citar parte de artigos sem autorização prévia desde que seja identificada a fonte. A reprodução total de artigos é proibida. Os artigos só devem ser usados para uso pessoal e nãocomercial. Em caso de dúvidas, consulte a redação: redacao@rae.com.br.

A RAE-eletrônica é a revista on-line da FGV-EAESP, totalmente aberta e criada com o objetivo de agilizar a veiculação de trabalhos inéditos. Lançada em janeiro de 2002, com perfil acadêmico, é dedicada a professores, pesquisadores e estudantes. Para mais informações consulte o site www.rae.com.br/eletronica.

RAE-eletrônica

ISSN 1676-5648

(C2004 Editora: Fundação Getulio Vargas - Escola de Administração de Empresas de São Paulo.

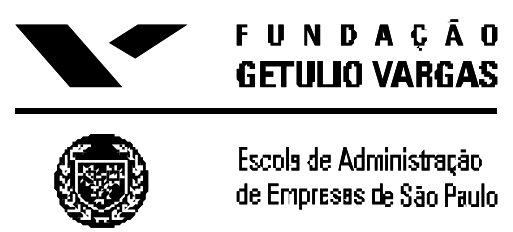




\author{
Por \\ Ângela Freitag Brodbeck \\ Profa. e Coordenadora da Área de Sistemas de Informação e Decisão da UFRGS-EA-PPGA. Doutora \\ em Administração de Empresas pelas UFRGS, ênfase em Sistemas de Informação e Decisão. \\ E-mail: angela@brodbeck.com.br
}

\title{
Sistemas Erp No Brasil: Teoria E Casos
}

De Cesar Alexandre de Souza e Amarolinda Zanela Saccol

Atlas, 2003, 368 p.

Sistemas ERP no Brasil é formado por uma coletânea de 16 trabalhos inéditos, distribuídos em cinco seções, agrupadas numa seqüência lógica de procedimentos para seleção, aquisição e implementação de sistemas integrados de gestão e focadas nos principais aspectos críticos relacionados às mudanças organizacionais. O texto apresenta uma visão unânime sobre a importância dos sistemas ERP para as organizações. Os casos relatados revelam que algumas organizações, independentes de porte e setor, encontram-se culturalmente mais abertas para mudanças, sendo favorecidas em todo o processo.

Os trabalhos de Souza e Zwicker apresentam modelos conceituais da tecnologia ERP abrangendo partes da cadeia de valor de Porter e do ciclo de vida deste sistema, seguidos pela apresentação de casos aplicados que podem contribuir com conhecimento para empresas que venham a implementar ERP ou até mesmo reavaliar suas implementações. Estes resultados aliados aos conceitos de administração de projetos complexos propostos por Medeiros e Ferreira e aos aspectos críticos apontados por Bergamaschi e Reinhard são contribuições significativas para trabalhos futuros sobre índices e informações referentes ao retorno sobre investimentos em novas tecnologias.

Porter e Millar vêem defendendo a idéia de que tecnologias agregam valor aos negócios, aumentando sua competitividade. No entanto, nas instalações iniciais dos ERPs, a idéia de sua utilização ficou travada, por assim dizer, em fatores como redução de custos operacionais e "bug" do milênio. A visão distorcida de redução de custos versus aumento de produtividade igual a demissões proporcionou muitos insucessos. Fatores como complexidade dos ambientes de negócio, cultura organizacional e aspectos metodológicos de implementação de novas tecnologias, foram ignorados.

Isto nos remete a seção dedicada às mudanças e impactos causados pelos ERPs. Ela contém artigos que relatam com profundidade alguns resultados obtidos através de observações em empresas na fase de estabilização do ciclo de vida destes sistemas. O seu valor encontra-se na percepção pósimplementação, ou seja, quais variáveis de negócio realmente foram afetadas; qual a percepção e satisfação do usuário-cliente acerca do novo sistema e da nova metodologia de trabalho; e qual o retorno sobre o investimento. O trabalho de abertura de Saccol, Macadar e Soares reporta provavelmente os fatores mais críticos de fracassos na adoção de ERPs. Variáveis de impacto na cultura organizacional, na motivação dos funcionários e nas suas habilidades podem ser cruciais durante a fase inicial de implementação.

O impacto dos ERPs pode ser sentido também no formato e padronização de gestão, conforme apresentado por Cardoso e Souza. Inicialmente, implementados para automatizar os processos operacionais, atualmente podem gerar informações para tomada de decisão em nível estratégico. Talvez seja neste ponto que o investimento sobre esta tecnologia tenha seu maior retorno: na agilidade, na 
confiabilidade, na rapidez da recuperação das informações para o ajuste ou até o redirecionamento de uma operação ou de todo o negócio.

A seção dedicada às pequenas e médias empresas retoma os modelos conceituais e metodológicos voltados para ambientes menos complexos. Os modelos são complementares e podem contribuir para empresas deste porte escolher e monitorar os fatores críticos de implementação desta tecnologia, espelhando-se em ocorrências anteriores e de maior abrangência. Isto poderá prover estas organizações de mecanismos de controle para que erros não sejam cometidos e acertos sejam reforçados, reduzindo o impacto e aumentando o retorno sobre o investimento. Vale destacar o último artigo da seção sobre desafios da implementação de um ERP focados em aspectos financeiros e funcionais, abordando a integração com os demais sistemas da cadeia de valor do negócio (fornecedores e clientes).

A última seção apresenta uma visão crítica do assunto, remetendo o leitor a um balanço entre as forças e fraquezas do uso de novas tecnologias. Wood, Paula e Caldas adotam a expressão "totalitarismo corporativo" para explicar alguns aspectos do fenômeno dos sistemas empresariais e das mudanças provocadas por eles em novos padrões de dominações nas organizações. Partindo de premissas como "na tecnologia não existem imperativos tecnológicos, mas escolhas organizacionais" e "todas as tecnologias são construções sociais, abertas a novas mudanças", Pozzebon e Pinsanneault discutem a perspectiva estruturacionista e as abordagens político-construtivistas, evidenciando uma visão mais interpretativa das tecnologias onde identificam-se situações de negociações e mudanças, levando o leitor a uma revisão dos princípios que permeiam as soluções integradas de gestão.

O texto do livro é oportuno por diversas razões. Durante toda a segunda metade da década de 1990 a tecnologia de ERP despontou como a solução para as organizações. Muitos foram os erros e acertos. A hora de reflexão é agora, onde novas tecnologias (SCM, CRM, KM) tornam-se cada vez mais frequientes, não podendo mais ser ignoradas. Por isso, o debate e o conhecimento dos diversos enfoques práticos é de extrema importância. Pela primeira vez na história, a prática e a teoria encontram-se intensamente casadas, mostrando que a integração entra as unidades de negócio internas e externas e o fluxo incessante de informação que cruza as fronteiras geográficas não é uma utopia. Esta interconectividade pode levar a um aumento da produtividade, ajudar as empresas a gerir seus estoques com níveis ótimos de eficiência, reduzir tempo e custos de processos do negócio e produzir apenas as demandas do mercado. Com certeza, empresas que adotem tais tecnologias irão crescer mais rapidamente e ser mais lucrativas do que aquelas que não reagirem de forma semelhante. E são nestes princípios que residem o valor desta obra, pelo aprendizado, pelos exemplos práticos e pelas reflexões que poderá nos proporcionar. 